\title{
Peningkatan Kemampuan Pemecahan Masalah Matematis Siswa SMP Melalui Pendekatan Saintifik Problem posing
}

\author{
(Improvement Of Mathematical Problem Solving Ability Of Junior High School Students \\ Through A Scientific Approach To Problem Posing)
}

\author{
Natsir $^{1}$, Kadir $^{2}$, Hafiludin Samparadja ${ }^{2}$ \\ ${ }^{1}$ Guru SMP Negeri 12 Kendari, Alumnus Prodi Pendidikan Matematika PPs Universitas Halu Oleo \\ ${ }^{2}$ Dosen Pendidikan Matematika FKIP dan PPS Universitas Halu Oleo; Co-author: kadirraea@yahoo.co.id
}

\begin{abstract}
Abstrak: Penelitian ini bertujuan untuk mengkaji peningkatan kemapuan pemecahan masalah matematis siswa smp melalui pendekatan saintifik problem posing. Penelitian ini mengggunakan desain pretest-posttest control group design. Populasi penelitian ini adalah seluruh siswa kelas VIII SMP Negeri 12 Kendari semester genap tahun pelajaran 2016/2017. Sampel penelitian diambil dua kelas dengan teknik purposive sampling dan untuk penentuan kelas eksperimen dan kelas kontrol menggunakan teknik simple random sampling. Hasil penelitian menunjukkan bahwa: (1) Aktivitas guru pada pembelajaran dengan pendekatan saintifik problem posing dan pendekatan saintifik sudah terlaksana dengan baik; (2) Aktivitas siswa pada pembelajaran dengan pendekatan saintifik problem posing terlaksana dengan baik; (3) Kemampuan pemecahan masalah matematis siswa pada kelas yang diajar dengan pendekatan pembelajaran saintifik problem posing dan siswa yang diajar dengan pendekatan saintifik masih berada pada kategori rendah.; (4) Terdapat peningkatan kemampuan pemecahan masalah matematis siswa setelah diajar dengan pendekatan saintifik problem posing; (5) Terdapat peningkatan kemampuan pemecahan masalah matematis siswa setelah diajar dengan pendekatan saintifik; dan (6) Peningkatan kemampuan pemecahan masalah matematis siswa yang diajar dengan pendekatan saintifik problem posing lebih tinggi daripada peningkatan kemampuan pemecahan masalah matematis siswa yang diajar dengan pendekatan saintifik.
\end{abstract}

Kata kunci: Pendekatan Saintifik, Pendekatan Saintifik Problem Posing, Kemampuan Pemecahan Masalah Matematis.

\begin{abstract}
This research aims to study the traffic increase in mathematical problem solving of students of junior high school through scientific approaches to problems of posing. This research using a pretest-posttest design control group design. The population of this research is the whole grade VIII SMP Negeri 12 Kendari even-numbered year semester lesson 2016/2017. Research samples taken two classes with a purposive sampling technique and for the determination of the class of the control classes and experiments using the technique of simple random sampling. The results showed that: (1) the activity of the teacher in the learning with the scientific approach to problem posing and scientific approaches have already done well; (2) the activity of students scientific approach to the study of problem posing to be implemented properly; (3) the ability of the mathematical problem solving of students in a class taught by scientific learning approach problem posing and the students taught with the scientific approach are still at a low category.; (4) there is an increase in the ability of the mathematical problem solving of students with scientific approach taught after problem posing; (5) there is an increase in the ability of the mathematical problem solving of students after the scientific approach is taught; and (6) Increased ability of the mathematical problem solving of students taught with the scientific approach of problem posing is higher than the increase in the ability of the mathematical problem solving of students taught with the scientific approach.
\end{abstract}

Keywords: Scientific Approaches, Scientific Approach To Problems Posing, Mathematical Problem Solving Ability.

\section{PENDAHULUAN}

Matematika sebagai ilmu dasar yang sangat erat kaitannya dengan kehidupan sehari-hari merupakan ilmu yang mempunyai peranan penting dalam

kehidupan manusia. Kristini (2007: 1) mengatakan bahwa peranan penting matematika dalam kehidupan manusia seharusnya membuat matematika menjadi 
mata pelajaran yang diminati dan menarik. Namun faktanya banyak siswa yang kurang menyukai matematika karena dianggap sulit dan tidak menarik.

Hasil studi pendahuluan yang dilaksanakan oleh peneliti di SMP Negeri 12 Kendari tahun 2015 menunjukkan bahwa tingkat kemampuan pemecahan masalah matematis siswa masih sangat rendah. Hal ini disebabkan oleh berbagai faktor, antara lain kurang tepatnya pendekatan pembelajaran yang diterapkan oleh guru dan siswa kurang dilatihkan soal-soal pemecahan masalah yang bersifat non rutin sehingga sebagian besar siswa tidak memahami masalah dengan baik dan tidak mengetahui strategi apa yang harus digunakan untuk menyelesaikan masalah yang diberikan.

Kemdikbud (2016: 4) menyatakan bahwa untuk meningkatkan kemampuan memecahkan masalah matematis siswa, perlu dikembangkan keterampilan memahami masalah, membuat model matematika, menyelesaikan masalah, dan menafsirkan solusinya. Keterampilanketerampilan tersebut dapat dimiliki oleh siswa kalau guru senantiasa memberikan soal rutin maupun soal non rutin melalui proses pembelajaran yang melibatkan keaktifan siswa melalui kegiatan mengamati, menanya, mengumpulkan informasi, mengolah informasi/menalar, dan mengkomunikasikan sesuatu persoalan menjadi lebih sederhana.

Pendekatan saintifik problem posing adalah suatu pendekatan pembelajaran yang menggerakkan siswa untuk mengajukan soal melalui proses mengamati, menanya, mengumpulkan informasi, mengolah informasi/menalar,

\section{METODE PENELITIAN}

Penelitian ini merupakan penelitian quasi experiment atau eksperimen semu dengan pretest-posttest control group design yang dilaksanakan di SMP Negeri 12 Kendari dengan bertujuan untuk mengetahui peningkatan kemampuan dan mengkomunikasikan suatu soal menjadi pertanyaan-pertanyaan yang lebih sederhana dengan tujuan untuk meningkatkan kemampuan intelek khususnya kemampuan berpikir tingkat tinggi siswa dan membentuk kemampuan siswa dalam menyelesaikan suatu masalah secara sistematik.

Anggo (2010: 1) mengungkapkan untuk memperoleh hasil dan manfaat optimal dari pemecahan masalah matematis siswa, perlu dilakukan langkahlangkah pemecahan yang terorganisasi dengan baik. Salah satu bentuk pengorganisasian untuk memecahkan masalah matematis adalah tahapantahapan yang dikemukakan oleh Polya (Sudia, 2014: 2), yaitu: (1) tahap memahami masalah; (2) tahap membuat rencana pemecahan masalah; (3) tahap melaksanakan rencana pemecahan masalah dan (4) tahap memeriksa kembali hasil pemecahan masalah.

Dari uraian di atas, maka peneliti memandang perlu untuk mengetahui peningkatan kemampuan pemecahan masalah matematik siswa SMP melalui pendekatan saintifik problem posing. Kemampuan pemecahan masalah matematis siswa dalam penelitian ini adalah kemampuan siswa dalam menerapkan pengetahuan yang telah diperoleh sebelumnya ke dalam situasi baru yang belum dikenal sebelumnya yang ditunjukkan melalui tahap memahami masalah, membuat rencana pemecahan masalah, melaksanakan rencana pemecahan masalah dan memeriksa kembali hasil pemecahan masalah.

pemecahan masalah matematis siswa SMP pada kelas diajar dengan pendekatan saintifik problem posing dan kelas yang diajar dengan pendekatan saintifik.

Populasi dalam penelitian ini adalah seluruh siswa kelas VIII SMP Negeri 12 
Kendari semester genap tahun pelajaran 2016/2017 yang tersebar ke dalam 7 kelas dengan jumlah siswa 230 orang. Sampel penelitian diambil sebanyak 2 kelas yang homogen dengan menggunakan teknik purposive sampling. Sedangkan untuk menentukan kelas ekperimen dan kelas kontrol menggunakan teknik simple random sampling. Kelas eksperimen adalah kelas VIII.4 yang terdiri dari 33 orang dan kelas VIII.1 yang terdiri dari 31 orang siswa sebagai kelas kontrol. Kelas eksperimen diajar dengan menggunakan pendekatan saintifik problem posing sedangkan kelas kontrol diajar dengan mengggunakan pendekatan saintifik.

Penelitian ini terdiri dari dua variabel, yaitu variabel bebas dan variabel terikat. Variabel bebas yang dimaksudkan adalah pendekatan pembelajaran (X). Sedangkan variabel terikat yang dimaksud adalah kemampuan pemecahan masalah matematis (Y).

Analisis data dalam penelitian ini meliputi analisis deskriptifi dan analisis inferensial. Analisis deskriptif digunakan untuk mendeskripsikan nilai yang

\section{HASIL PENELITIAN}

Data hasil penelitian diperoleh melalui lembar observasi keterlaksanaan pembelajaran dan instrumen tes kemampuan pemecahan masalah diperoleh masing-masing kelas dalam bentuk rata-rata, nilai maksimum, nilai minimum, dan standar deviasi serta mendeskripsikan aktivitas guru dan siswa dalam proses pembelajaran. Sedangkan analisis inferensial digunakan untuk menguji hipotesis penelitian namun terlebih dahulu dilakukan uji normalitas dan uji homogenitas sebagai uji prasyarat untuk melakukan uji hipotesis. Data yang digunakan dalam uji normalitas dan uji-t berbentuk skor Normalized Gain (NGain). Data kuantitaif ditabulasi dan dianalisis dengan melakukan analisis deskriptif dengan menghitung gain ternormalisasi (N-Gain) posttes dan pretest. Gain adalah selisih antara nilai posttest dan pretest, gain menunjukkan peningkatan kemampuan pemecahan masalah matematis setelah pembelajaran dilakukan oleh guru. Uji normalitas data menggunakan uji Kolmogorov-Smirnov dan uji homogenitas menggunakan uji Levene. Uji hipotesis menggunakan uji $\mathrm{t}$ yaitu paired sample t-test dan independen sample t-test.

matematis (KPMM) siswa dan. Deskripsi keterlaksanaan pembelajaran dapat dilihat pada Tabel 1 dan Tabel 2 berikut.

Tabel 1. Deskripsi Keterlaksanaan Pembelajaran oleh Guru

\begin{tabular}{lccccccc}
\hline $\begin{array}{l}\text { Persentase Aktivitas } \\
\text { Pembelajaran }\end{array}$ & $\mathbf{1}$ & $\mathbf{2}$ & $\mathbf{3}$ & $\mathbf{4}$ & $\mathbf{5}$ & $\mathbf{6}$ & Rata (\%) \\
\hline Saintifik Problem Posing & 76,25 & 82,50 & 88,75 & 95,00 & 96,25 & 97,50 & 89,38 \\
Saintifik & 78,75 & 83,75 & 88,75 & 91,25 & 92,5 & 97,50 & 88,75 \\
\hline
\end{tabular}

Tabel 2. Deskripsi Aktivitas Siswa dalam Proses Pembelajaran

\begin{tabular}{lccccccc} 
Persentase Aktivitas & \multicolumn{4}{c}{ Pertemuan ke } & \multicolumn{2}{c}{ Rata-rata } \\
Pembelajaran & $\mathbf{1}$ & $\mathbf{2}$ & $\mathbf{3}$ & $\mathbf{4}$ & $\mathbf{5}$ & $\mathbf{6}$ & $(\mathbf{\%})$ \\
\hline Saintifik Problem Posing & 66,67 & 77,78 & 84,72 & 93,06 & 94,44 & 95,83 & 85,42 \\
Saintifik & 65,27 & 72,22 & 81,94 & 86,11 & 87,5 & 94,44 & 81,27 \\
\hline
\end{tabular}


Tabel 1 memberikan gambaran bahwa pembelajaran dengan pendekatan saintifik problem posing dan pendekatan saintifik sudah terlaksana dengan sangat baik dan Tabel 2 memberikan gambaran bahwa aktivitas siswa dalam pembelajaran dengan pendekatan saintifik problem posing dan pendekatan saintifik termasuk kategori sangat baik.
Tes KPMM baik pada kelas eksperimen maupun kelas kontrol dilakukan dua kali, yaitu sebelum pemberian perlakuan (pretest) dan setelah perlakuan (posttest). Dari skor pretest dan psottest, selanjutnya dihitung $N$-Gain KPMM. Perhitungan KPMM sebelum perlakuan (pretest) dan setelah perlakuan (posttest) dapat dilihat pada Tabel 3.

Tabel 3. Hasil Tes KPMM sebelum perlakuan (pretest) dan setelah perlakuan

\begin{tabular}{ccccccc}
\multicolumn{8}{c}{ Posttest) } \\
\hline \multirow{2}{*}{ Statistik } & $\begin{array}{c}\text { Saintifik Problem Posing } \\
\text { Pretest }\end{array}$ & Posttest & N-Gain & Pretest & Paintifik & \\
& 33 & 33 & 33 & 31 & 31 & 31 \\
N & 36,79 & 49,33 & 0,21 & 28,84 & 37,23 & 0,13 \\
Rata-rata & 33 Nost & N-Gain \\
Standar Deviasi & 12,44 & 15,25 & 0,13 & 13,69 & 18,12 & 0,13 \\
Maksimum & 58,00 & 72,00 & 0,42 & 72,00 & 84,00 & 0,43 \\
Minimum & 6,00 & 14,00 & $-0,03$ & 6,00 & 4,00 & $-0,06$ \\
\hline
\end{tabular}

Tabel 3 memberikan gambaran bahwa $N$-Gain pada kelas yang diajar dengan pendekatan saintifik problem posing maupun pada kelas yang diajar dengan pendekatan saintifik tergolong masih rendah. Hal ini ditunjukkan dengan rata-rata $\mathrm{N}$-Gain pada kelas eksperimen sebesar 0,21 dan $\mathrm{N}$-Gain pada kelas kontrol yang hanya sebesar 0,13 . Namun demikian, setelah proses pembelajaran, terjadi peningkatan kemampuan pemecahan masalah matematis siswa pada kedua kelas pembelajaran. Hal ini selain ditunjukkan N-gain, juga ditunjukkan oleh skor rata-rata kemampuan pemecahan masalah matematis siswa yang diajar dengan menggunakan pendekatan saintifik problem posing memperoleh sebesar 49,33 meningkat sebesar 12,54 sedangkan siswa yang diajar dengan menggunakan pendekatan sanitifik memperoleh rata-rata 37,23 meningkat sebesar 8,39. Hal tersebut menunjukkan bahwa peningkatan kemampuan pemecahan masalah matematis siswa yang diajar dengan menggunakan pendekatan saintifik problem posing lebih tinggi dibandingkan dengan siswa yang diajar dengan menggunakan pendekatan saintifik.

Uji normalitas peningkatan kemampuan pemecahan masalah matematis dari kedua kelas pembelajaran tersebut disajikan pada Tabel 4.

Tabel 4. Uji Nomalitas Data KPMM Siswa

\begin{tabular}{cccccc}
\hline Pendekatan & N & Rerata & $\begin{array}{c}\text { Kolmogorov- } \\
\text { Smirnov Z }\end{array}$ & $\begin{array}{c}\text { Asymp. } \\
\text { Sig. }\end{array}$ & $\mathbf{H}_{\mathbf{0}}$ \\
\hline Saintifik Problem Posing & 33 & 36,79 & 0,498 & 0,965 & Terima \\
Saintifik & 31 & 28,84 & 0,996 & 0,274 & Terima \\
\hline
\end{tabular}


Tabel 4 menunjukkan bahwa kedua nilai probabilitas (Sig.) pada kelas yang diajar dengan pendekatan saintifik problem posing sebesar 0,965 , dan kelas yang diajar dengan pendekatan saintifik sebesar 0,274. Nilai sig. masing-masing kelas pembelajaran tersebut lebih besar dari $\alpha=0,05$ sehingga $\mathrm{H}_{0}$ diterima. Dengan demikian, dapat disimpulkan bahwa data kedua kelas pembelajaran berasal dari populasi berdistribusi normal. Selanjutnya dilakukan pengujian homogenitas kemampuan pemecahan masalah matematis siswa dan varians antara kedua kelas pembelajaran dengan menggunakan uji Levene. Uji homogenitas dan varians data peningkatan kemampuan pemecahan masalah matematis siswa disajikan pada Tabel 5.

Tabel 5. Uji Homogenitas dan Varians Data Peningkatan KPMM Siswa

\begin{tabular}{lcc}
\multicolumn{1}{c}{ N-Gain } & \multicolumn{2}{c}{ Levene's Test for Equality of } \\
& F & Variances \\
& Sig. \\
\hline $\begin{array}{l}\text { N-Gain Kemampuan Pemecahan } \\
\text { Masalah Matematis }\end{array}$ & 0.427 & 0,516 \\
\hline
\end{tabular}

Tabel 5 menunjukkan bahwa nilai probabilitas (Sig.) sebesar 0,516 lebih besar dari $\alpha=0,05$ yang berarti $\mathrm{H}_{0}$ diterima. Dengan demikian, dapat disimpulkan bahwa data kedua kelas pembelajaran memiliki varians yang homogen.
Uji signifikansi yang digunakan untuk menguji peningkatan kemampuan pemecahan masalah matematis siswa pada penerapan pendekatan saintifik problem posing dan pendekatan saintifik adalah uji $\mathrm{t}$ untuk data tidak berpasangan yang disajikan pada Tabel 6 .

Tabel 6 Uji Perbedaan Signifikansi Peningkatan Kemampuan Pemecahan Masalah Matematis Siswa dari Kedua Kelas Pembelajaran

\begin{tabular}{lccccccc}
\hline \multicolumn{1}{c}{ Pendekatan } & N & Rerata & $\begin{array}{c}\text { Standar } \\
\text { Deviasi }\end{array}$ & $\mathbf{t}$ & Df & Sig. & $\mathbf{H}_{\mathbf{0}}$ \\
\hline Saintifik Problem Posing & 33 & 0,455 & 0,173 & & & & \\
Saintifik & 31 & 0,335 & 0,158 & & & & \\
\hline
\end{tabular}

Berdasarkan hasil uji pada Tabel 6 , menunjukkan bahwa nilai t sebesar 2,795 dan $\frac{1}{2}$ nilai probabilitas (Sig.) adalah $0,0035<\alpha=0,05$, sehingga $\mathrm{H}_{0}$ ditolak. Dengan dierimanya $\mathrm{H}_{0}$, maka dapat dikatakan bahwa peningkatan kemampuan pemecahan masalah matematis siswa yang diajar dengan pendekatan saintifik problem posing lebih tinggi daripada peningkatan kemampuan pemecahan masalah matematis siswa yang diajar dengan pendekatan saintifik. Hal tersebut diperkuat dengan melihat nilai rata-rata $\mathrm{N}$ Gain yang diperoleh dari kedua kelas pembelajaran dimana nilai rata-rata $N$ Gain siswa yang diajar dengan pendekatan saintifik problem posing adalah sebesar 0,455 (berada pada kategori sedang) lebih tinggi dibandingkan dengan nilai rata-rata $N$-Gain siswa yang diajar dengan pendekatan saintifik yang hanya sebesar 0,335 (berada pada kategori sedang).

Hasil analisis yang dilakukan terhadap hasil kerja siswa dalam memecahkan tes kemampuan pemecahan 
masalah matematis berdasarkan Tabel 7.

pendekatan pembelajaran disajikan pada

Tabel 7. Rata-rata Setiap Indikator KPMM Siswa pada Kedua Pendekatan

Pembelajaran

\begin{tabular}{|c|c|c|c|c|c|c|}
\hline \multirow{3}{*}{$\begin{array}{l}\text { Aspek Yang } \\
\quad \text { Diukur }\end{array}$} & \multicolumn{6}{|c|}{$\begin{array}{c}\text { Rata-rata Kemampuan Pemecahan Masalah Matematis } \\
\text { Terhadap Pendekatan yang Digunakan }\end{array}$} \\
\hline & \multicolumn{3}{|c|}{ Saintifik Problem Posing } & \multicolumn{3}{|c|}{ Saintifik } \\
\hline & Pretest & Posttest & Peningkatan & Pretest & Posttest & Peningkata \\
\hline $\begin{array}{l}\text { Memahami } \\
\text { Masalah }\end{array}$ & 77,88 & 90,61 & 12,73 & 65,81 & 77,42 & 11,61 \\
\hline Merencanakan & & & & & & \\
\hline $\begin{array}{c}\text { Pemecahan } \\
\text { Masalah }\end{array}$ & 41,21 & 52,22 & 11,01 & 33,12 & 43,01 & 9,89 \\
\hline $\begin{array}{c}\text { Melaksanakan } \\
\text { Rencana }\end{array}$ & 20,01 & 30,50 & 9,49 & 17,63 & 24,09 & 6,45 \\
\hline $\begin{array}{c}\text { Memeriksa } \\
\text { Kembali Hasil }\end{array}$ & 12,42 & 20,61 & 8,19 & 3,44 & 8,06 & 4,62 \\
\hline
\end{tabular}

Tabel 7 menunjukkan bahwa terjadi peningkatan pada setiap indikator kemampuan pemecahan masalah matematis siswa setelah siswa diajar dengan pendekatan saintifik problem posing. Begitu pula dengan siswa yang diajar dengan pendekatan saintifik terjadi peningkatan pada setiap indikator kemampuan pemecahan masalah matematis baik pada aspek memahami masalah, merencanakan pemecahan masalah, melaksanakan rencana, maupun pada aspek memeriksa kembali hasil. Tetapi peningkatan pada setiap indikator kemampuan pemecahan masalah matematis siswa yang diajar dengan menggunakan pendekatan saintifik problem posing lebih tinggi daripada siswa yang diajar dengan menggunakan pendekatan saintifik. Untuk siswa yang diajar dengan pendekatan saintifik problem posing, pada aspek memahami

\section{PEMBAHASAN}

Berdasarkan hasil penelitian yang telah diuraikan sebelumnya, dapat diketahui bahwa faktor pendekatan yang digunakan guru dalam pembelajaran dapat mempengaruhi keaktifan siswa selama masalah terjadi peningkatan rata-rata sebesar 12,73; merencanakan pemecahan masalah sebesar 11,01; melaksanakan rencana sebesar 9,49, dan memeriksa kembali hasil sebesar 8,18. Sedangkan untuk siswa yang diajar dengan menggunakan pendekatan saintifk, terjadi peningkatan rata-rata pada aspek memahami masalah terjadi sebesar 11,61; merencanakan pemecahan masalah sebesar 9,89; melaksanakan rencana sebesar 6,45 dan memeriksa kembali hasil sebesar 4,62. Berdasarkan data tersebut di atas, maka dapat disimpulkan bahwa siswa yang diajar dengan pendekatan saintifik problem posing memperoleh peningkatan yang lebih tinggi pada setiap indikator kemampuan pemecahan masalah matematis dibandingkan dengan siswa yang diajar dengan pendekatan saintifik.

mengikuti proses pembelajaran. Peningkatan aktivitas siswa dalam mengikuti proses pembelajaran ikut pula meningkatkan kemampuan pemecahan masalah matematis siswa. Keterlaksanaan 
pembelajaran dengan pendekatan saintifik problem posing sebanyak enam kali pertemuan, pada kelas eksperimen diperoleh rata-rata persentase sebesar $89,38 \%$. Sedangkan pada kelas kontrol diperoleh rata-rata persentase sebesar $88,75 \%$. Ini menunjukkan bahwa pembelajaran pada kedua kelompok pembelajaran dengan sudah terlaksana dengan baik.

Aktivitas siswa selama pelaksanaan pembelajaran dengan pendekatan saintifik problem posing pada kelas eksperimen diperoleh rata-rata sebesar 85,42\% sedangkan pembelajaran dengan pendekatan saintifik pada kelas kontrol diperoleh rata-rata sebesar $81,19 \%$. Berdasarkan kriteria dikemukakan oleh Purwanto (2010: 102) bahwa keterlaksanaan pembelajaran yang berada pada persentase $80 \% \quad-\quad 100 \%$ dikategorikan sangat baik, maka dapat dikatakan bahwa pembelajaran dengan pendekatan saintifik problem posing pada kelas eksperimen dan pendekatan saintifik pada kelas kontrol sudah terlaksana dengan sangat baik.

Hal ini sesuai dengan pendapat Lie (2002: 43) yang menyatakan bahwa kelompok heterogen memberi kesempatan untuk saling mengajar (peer tuto-ring) dan saling mendukung. Selain itu pembagian kelompok juga menimbulkan semangat kebersamaan dari anggota kelompok untuk dapat berprestasi lebih baik dari kelompok lain. Sehingga siswa yang berpengetahuan lebih tinggi dalam kelompoknya akan berupaya membantu siswa lain yang berpengetahuan kurang. Siswa yang berpengetahuan lebih tinggi menjadi guru bagi siswa lain, dan siswa yang berpengetahuan kurang mendapat guru dari teman sekelompoknya, sehingga terjadi hubungan yang bersifat saling menguntungkan. Lie (2002: 43) menyatakan bahwa kelompok heterogen memudahkan pengelolaan kelas, karena adanya satu orang yang berkemampuan akademis tinggi menjadi tutur sebaya bagi yang lain, sehingga memungkinkan guru mendapatkan asisten selama proses pembelajaran berlangsung. Hal ini akan banyak membantu siswa yang lain untuk memperoleh kemampuan pemecahan masalah secara optimal. Dengan demikian dapat dikatakan bahwa melalui penerapan pendekatan pembelajaran saintifik problem posing, siswa mendapatkan pembelajaran yang bermakna karena siswa terlibat secara aktif dalam kegiatan pempelajaran untuk mempelajari konsepkonsep yang berhubungan dengan pemecahan masalah secara matematis dengan menggunakan metode ilmiah untuk menyelesaikan masalah melalui pengajuan soal atau masalah.

Berdasarkan analisis deskriptif yang telah dikemukakan sebelumnya, secara umum kemampuan pemecahan masalah matematis siswa baik pada kelas eksperimen maupun pada kelas kontrol terjadi peningkatan walaupun dengan kategori rendah. Hal tersebut ditunjukkan oleh rata-rata peningkatan kemampuan pemecahan masalah matematis pada kelas eksperimen adalah sebesar 12,54 dengan rata-rata $\mathrm{N}$-Gain sebesar 0,21 dan nilai rata-rata kemampuan pemecahan masalah matematis siswa pada kelas kontrol sebesar 8,39 dengan rata-rata $\mathrm{N}$-Gain sebesar 0,13. Dari hasil tersebut menunjukkan bahwa kemampuan pemecahan masalah matematis siswa yang diajar dengan pendekatan saintifik problem posing terjadi peningkatan. Begitu pula kemampuan pemecahan masalah matematis siswa pada kelas yang diajar dengan pendekatan saintifik tejadi peningkatan. Peningkatan kemampuan memecahkan masalah matematis pada kelas eksperimen mempunyai rata-rata yang lebih tinggi daripada kelas kontrol. Peningkatan kemampuan pemecahan masalah matematis siswa pada kelas yang diajar dengan saintifik problem posing maupun pada kelas yang diajar dengan saintifik ditunjang oleh keterlaksanaan proses pembelajaran yang baik. Hasil ini 
relevan dengan hasil penelitian yang dilaksanakan oleh Dangga (2015) menyatakan bahwa siswa yang mendapat pembelajaran dengan pendekatan pembelajaran saintifik problem posing

\section{KESIMPULAN DAN SARAN}

Berdasarkan hasil penelitian dan pembahasan yang telah dikemukakan pada bab sebelumnya dapat dikemukakan beberapa kesimpulan sebagai berikut: (1) Pendekatan saintifik problem posing mempunyai persentase rata-rata sebesar $89,38 \%$ dan pendekatan saintifik sebesar $88,75 \%$. (2) Aktivitas siswa dalam pembelajaran dengan pendekatan saintifik problem posing dan pendekatan saintifik termasuk kategori sangat baik yaitu sebesar $85,42 \%$ dan pendekatan saintifik sebesar 81,19\%; (3) Kemampuan pemecahan masalah matematis siswa pada kelas yang diajar dengan pendekatan pembelajaran saintifik problem posing dan siswa yang diajar dengan pendekatan saintifik masih berada pada kategori rendah. Hal ini ditunjukkan dengan ratarata pretest kemampuan pemecahan masalah matematis siswa sebesar 36,79 dan pada posttets sebesar 49,33 dengan $\mathrm{N}$ -

\section{DAFTAR PUSTAKA}

Anggo, Mustamin. 2010. Proses Metakognisi Mahasiswa Calon Guru Dalam Pemecahan Masalah Matematika. Disertasi. PPs Pendidikan Matematika Universitas Negeri Surabaya. Tidak diterbitkan.

Dangga, Sriwati. 2015. Efketivitas Pendekatan Scientific Problem posing dan Pendekatan Scientific Terhadap Kemampuan Penalaran dan Literasi Matematis Siswa. Tesis. Program Studi Pendidikan Matematika Program Pascasarjana Universitias Halu Oleo. Kendari. Tidak Dipublikasikan.

Kemendikbud. 2016. Materi Pelatihan Guru Implementasi Kurikulum 2013 Sekolah Menengah Pertama memperoleh kemampuan penalaran matematis yang lebih baik daripada siswa yang mendapat pendekatan pembelajaran saintifik.

gain sebesar 0,21. Rata-rata pretest kemampuan pemecahan masalah matematis siswa pada kelas yang mendapat pembelajaran saintifik sebesar 28,84 dan pada posttest mempunyai ratarata sebesar 37,23 dengan $\mathrm{N}$-gain sebesar 0,13 ; (4) Terdapat peningkatan kemampuan pemecahan masalah matematis siswa setelah diajar dengan pendekatan saintifik problem posing; (5) Terdapat peningkatan kemampuan pemecahan masalah matematis siswa setelah diajar dengan setelah diajar dengan pendekatan saintifik;

Peningkatan kemampuan pemecahan masalah matematis siswa yang diajar dengan pendekatan saintifik problem posing lebih tinggi daripada peningkatan kemampuan pemecahan masalah matematis siswa yang diajar dengan pendekatan saintifik.

Mata Pelajaran Matematika. Jakarta: Depdikbud.

Lie, A. 2002. Cooperative Learning, Mempraktekkan Cooperative Learning di Ruang-ruang Kelas. Jakarta: Gramedia.

Purwanto. 2010. Evaluasi Hasil Belajar. Yogyakarta: Pustaka Pelajar.

Polya, G. 1973. How to Solve it. New Jersey: Princeton University Press.

Sudia, M. 2014 . Profil Metakognisi Siswa SMP dalam Memecahkan Masalah Terbuka Ditinjau dari Perbedaan Gender. Jurnal Jurusan Pendidikan Matematika FKIP Universitas Halu Oleo, Januari 2014, ISBN 2086-8235, hal. 2. 